\title{
Allelopathic effects of Alexandrium tamarense on other algae: evidence from mixed growth experiments
}

\author{
Urban Tillmannn ${ }^{1, *}$, Per Juel Hansen ${ }^{2}$ \\ ${ }^{1}$ Alfred-Wegener Institut für Polar und Meeresforschung, Am Handelshafen 12, 27570 Bremerhaven, Germany \\ ${ }^{2}$ Marine Biological Laboratory, Strandpromenaden 5, 3000 Helsingør, Denmark
}

\begin{abstract}
The effect of 2 strains (Alex2 and Alex5) of the marine red tide dinoflagellate Alexandrium tamarense on 10 other planktonic algal target species common in temperate waters was studied in mixed growth experiments under nutrient-rich conditions. In a comparative approach, the 2 strains of A. tamarense, similar in their cellular paralytic shellfish toxin (PST) content, were selected because of their fundamentally different lytic potencies. The Alex2 strain clearly affected all target algae while the Alex5 strain had no negative effect on the growth of any of the target species during the study period, even though cell concentrations of Alex5 became very high $\left(2 \times 10^{4} \mathrm{cells} \mathrm{ml}^{-1}\right)$. As both strains contained comparable amounts of PST, this confirmed previous suggestions that so far unidentified compounds are causing the negative effects on other algae. Sensitivity of the tested algae to Alex2 differed considerably. The growth of some species was affected at very low Alex2 cell concentrations $\left(<10^{2}\right.$ cells ml $\left.{ }^{-1}\right)$, while the growth of other algae was not affected until cell concentrations exceeded $10^{3}$ cells ml-1 ${ }^{-1}$. While a complete dieoff was the ultimate fate for almost all target species when grown in mixed culture with Alex2, Scrippsiella trochoidea formed temporary cysts, the number of which remained constant during the course of the experiment. The $\mathrm{pH}$ in the mixed cultures increased as the cultures grew dense. This had a substantial effect on Alex5 in the mixed cultures, in which Alex5 eventually died off because the target species have a higher tolerance to high $\mathrm{pH}$. $\mathrm{pH}$ values did not determine the outcome of the experiments with Alex2 because the adverse effects of Alex2 on the growth of the other algae was evident before $\mathrm{pH}$ values became too high. Lytic extracellular compounds, which are produced by the large majority of $A$. tamarense strains tested so far, clearly have the potential to benefit this dinoflagellate by reducing competitor growth rates.
\end{abstract}

KEY WORDS: Alexandrium $\cdot$ PST $\cdot$ Paralytic shellfish toxin $\cdot$ Allelopathy $\cdot$ Growth $\cdot$ Algae $\cdot \mathrm{pH}$

\section{INTRODUCTION}

Species of the dinoflagellate genus Alexandrium are widely distributed in temperate, subtropical and tropical coastal waters. They have received much attention over the past $50 \mathrm{yr}$ because they are toxic. Their toxicity has been shown to affect an extraordinarily wide spectrum of organisms including humans as consumers of contaminated seafood, large multicellular organisms like fish, mussels, and marine mammals, and competitors (other microalgae) as well as protistan and metazoan grazers. This broad range of target organisms is explained by the fact that Alexandrium species are able to produce a whole suite of different toxins. Best known are the paralytic shellfish toxins (PSTs), of which 24 naturally occurring derivatives have now been described (Shimizu 1996). These are potent neurotoxins with sodium channel blocking activity, and they are responsible for the reported toxic effects of Alexandrium spp. on marine mammals and humans (Cembella 2003).

For a long time, PSTs were also suspected to be responsible for the effects of Alexandrium spp. on metazoan and protistan grazers and algal competitors (Sykes \& Huntley 1987, Hansen 1989, Hansen et al. 
1992, Fulco 2007). Turner et al. (1998) compiled data on the effects of Alexandrium spp. on copepods and reached the conclusion that PSTs most likely were not involved in the effects observed on copepods. With respect to protistan targets, it is now quite clear that PSTs are not involved in the negative observed effects (Tillmann \& John 2002, Tillmann et al. 2008a). Thus, it is evident that Alexandrium spp. produce some as yet unknown compounds with lytic capabilities in addition to the neurotoxic PSTs, and that these unknown compounds are responsible for the effects on algae and protistan grazers. Chemically mediated effects of planktonic algae on competitors and/or micrograzers have recently gained much interest and have been covered in a number of comprehensive reviews (Cembella 2003, Legrand et al. 2003, Granéli \& Hansen 2006, Tillmann et al. 2008b).

Six species of Alexandrium have so far been shown to have the ability to kill other algae and heterotrophic protists (Tillmann et al. 2008a). Among the initial sublethal effects on tintinnids are alterations of swimming speed and pattern, including backwards swimming (Hansen 1989, Hansen et al. 1992, Fulco 2007). After a few minutes of exposure, cells tend to swell and subsequently lyse. The notion that the unknown Alexandrium spp. lytic compounds may primarily act on cell membranes suggests that they may also cause the death of fish by destroying their gills (Mortensen 1985, Cembella et al. 2002).

In contrast to the PSTs, which are mainly stored inside the cells, the toxicity of Alexandrium spp. for other protists is caused by lytic compounds that are excreted into the medium (Hansen 1989, Tillmann \& John 2002, Fistarol et al. 2004b, Tillmann et al. 2008b). These extracellular compounds can directly affect heterotrophic protists without Alexandrium spp. being ingested. In fact, heterotrophic protists may grow just as well on PST-containing Alexandrium spp. cells as on other prey organisms (Hansen 1989, Hansen et al. 1992, Kamiyama \& Suzuki 2006) without any apparent effects of the incorporated PSTs.

A number of factors determine how Alexandrium spp. affects other protists. For the lytic species and strains studied so far, the cell concentration of Alexandrium spp. is very important. Not surprisingly, the negative effect is always most pronounced at high Alexandrium spp. cell concentrations. However, considerable variation in toxicity towards target cells occurs among species/strains. Some species or strains are apparently lytic at very low cell concentrations $\left(\mathrm{EC}_{50}<10\right.$ to 40 cells $\mathrm{ml}^{-1}$ ), while others need to be present in much higher concentrations (>7000 cells $\mathrm{ml}^{-1}$ ) to kill target cells (Hansen 1989, Hansen et al. 1992, Tillmann et al. 2008a). Almost all Alexandrium species and strains tested so far have been shown to negatively affect other protists. However, while most target cells that have been tested are killed by Alexandrium spp., a few species/strains seem insensitive to Alexandrium lytic compounds, even at very high cell concentrations (Tillmann et al. 2007).

Nearly all previous experiments were performed over short exposure periods lasting from minutes up to $24 \mathrm{~h}$. It has been shown that the length of the incubation time may lead to considerable differences in the response of target species to Alexandrium spp. (Hansen 1989). Thus, even though Alexandrium spp. can kill target cells in minutes if cell concentrations of the dinoflagellate are very high, sub-lethal cell concentrations may take several days to affect target cells negatively, leading to a reduced growth rate of the target cells. Thus, there is clearly a need for studies focussing on long-term exposure of different target cells to Alexandrium spp. This can be achieved by carrying out mixed growth experiments of Alexandrium spp. and selected target algae.

Such experiments are not trivial, because a number of factors may influence their outcome (see Schmidt \& Hansen 2001), making interpretations difficult. The main difficulty is to unambiguously separate effects caused by allelochemicals from other effects such as direct competition for nutrients or other interspecific interactions like mixotrophy or predation. The potentially most confounding problem arises from changing $\mathrm{pH}$ levels in mixed batch cultures in combination with species-specific pH limits of growth (Hansen 2002). Some of these problems might be avoided by exposing target cells to culture filtrate of the donor species. However, this approach has limited value because some toxins cannot be quantitatively filtered (Ulitzur 1973, Tillmann et al. 2008b) or are labile, so toxic effects may cease after some time because compounds are not exuded continuously as in the case of mixed cultures (Granéli \& Hansen 2006).

An elegant way to overcome all these problems is a comparative approach using different strains of the same algal species that are virtually identical in all aspects except toxicity. In a detailed study to simultaneously investigate genotypic diversity and phenotypic variation among clonal isolates from a single Alexandrium tamarense population (Alpermann et al. 2009), a total of 67 clonal cultures were screened for their allelochemical potency and found to be very variable in their expression of lytic properties. Only 2 of these 67 clonal isolates did not cause severe damage to Rhodomonas salina target cells in a short-term bioassay, indicating that the absence of measurable lytic activity within different strains of $A$. tamarense is a rare exception. The non-lytic clonal $A$. tamarense strains, together with well characterised lytic strains now available (Tillmann et al. 2009), represent perfect tools 
to analyze various aspects of the ecological effects and consequences of being lytic in a comparative approach.

The aim of the present study was to investigate the growth response of Alexandrium tamarense and other competing microalgae when grown in mixed cultures. By comparing the effects of a lytic with an apparently non-lytic strain of A. tamarense in mixed cultures, we were able to unambiguously attribute the observed effects to allelochemical interactions.

\section{MATERIALS AND METHODS}

Algal cultures. Two clonal strains of Alexandrium tamarense, Alex2 and Alex5, were used in the experiments. Both were isolated from one plankton net haul from coastal waters of the Scottish North Sea coast by micro-capillary isolation of single cells (for details see Alpermann et al. 2009). These 2 strains were selected out of about 100 clonal strains (all originating from the same net haul) based on their different lytic capacity as quantified by a Rhodomonas bioassay (Tillmann et al. 2009). Ten different target species, all common in temperate waters and representing different systematic affiliations were obtained from various culture collections. The dimensions of the target species were measured on live cells under the microscope ( $\mathrm{n}=20$ to 30 cells), and cell volumes were estimated using simple volumetric formulae (Table 1).

All stock cultures were grown non-axenically in $\mathrm{K}$ medium (Keller et al. 1987), supplemented with selenite (Dahl et al. 1989) prepared from $0.2 \mu \mathrm{m}$ sterile-filtered (VacuCap, Pall Life Sciences) natural North Sea water (salinity 32, pH adjusted to 8.0) in $500 \mathrm{ml}$ Erlenmeyer flasks under controlled conditions at $15^{\circ} \mathrm{C}$ with artificial light at a photon flux density of $100 \mu \mathrm{mol} \mathrm{m}{ }^{-2}$ $\mathrm{s}^{-1}$ (provided by cool white fluorescent lamps) on a 16:8 h light:dark cycle. Stock cultures were diluted regularly and were in exponential growth at the start of the experiment.

Experimental design. Cell concentrations in all stock cultures were estimated by microscopic cell counts. Triplicate mixtures (100 ml mixture in $100 \mathrm{ml}$ Erlenmeyer flasks) of each Alexandrium tamarense strain and each target species were prepared to initial concentrations of about 100 cells $\mathrm{ml}^{-1}$ for each species, with the exception of Ceratium lineatum, for which an initial concentration of 500 cells $\mathrm{ml}^{-1}$ was chosen. In addition, triplicate monocultures for each species and A tamarense strain were set up, resulting in 96 flasks in total. After mixing, $2 \mathrm{ml}$ samples were taken to measure initial algal cell concentrations.

Flasks were placed randomly on an illuminated bench (100 $\mu \mathrm{mol} \mathrm{m} \mathrm{m}^{-2} \mathrm{~s}^{-1}, 16: 8 \mathrm{~h}$ light:dark cycle) in a temperature-controlled culture room at $15^{\circ} \mathrm{C}$. To avoid small differences in light exposure, positions of the flasks were randomized every day. At the beginning, daily samples $(2 \mathrm{ml})$ for cell counts were taken from each flask. As soon as a target species in mixtures with Alexandrium tamarense strain Alex2 was no longer detectable, sampling frequency was reduced to every $2 \mathrm{~d}$. Every second day, $\mathrm{pH}$ was measured directly in the experimental flasks using an EcoScan pH5 (Eutech Instruments) pH-meter. Sampling was terminated when a target species reached stationary growth phase.

Cell counts and growth rate calculation. All counts of donor and target cell concentrations were performed on samples fixed with Lugol's (final concentration $2 \%$ ) and using an inverted microscope (Zeiss Axiovert 40 C). Depending on the cell concentration, the volume for cell counts varied from 0.1 to $2 \mathrm{ml}$. Whole chambers or representative sub-areas were counted. The total number of cells counted per species was always $>400$ cells

Table 1. Target species cultures, their approximate cell volume and origin. CCMP: Provasoli-Guillard National Center for Culture of Marine Phytoplankton; KAC: Kalmar Culture Collection; SAG: Culture Collection of Algae at the University of Göttingen; AWI: Alfred Wegener Institute for Polar and Marine Research; SCCAP: Scandinavian Culture Collection of Algae and Protozoa; MBL: Marine Biological Laboratory

\begin{tabular}{|lccl|}
\hline Species & Strain no. & $\begin{array}{c}\text { Approx. size } \\
\text { (cell volume, } \mathrm{m}^{3} \text { ) }\end{array}$ & Collection/origin (if known) \\
\hline Rhodomonas salina (Cryptophyceae) & KAC30 & 250 & KAC \\
Dunaliella salina (Chlorophyceae) & - & 590 & AWI \\
Skeletonema costatum (Bacillariophyceae) & SAG 19.99 & 200 & SAG \\
Thalassiosira weisflogii (Bacillariophyceae) & - & 900 & AWI \\
Ceratium lineatum (Dinophyceae) & - & 8100 & MBL/The Sound, Denmark, 1995 \\
Prorocentrum minimum (Dinophyceae) & SCCAP K-0295 & 1040 & SCCAP Kattegat, Denmark, 1989 \\
Scrippsiella trochoidea (Dinophyceae) & - & 1500 & AWI/North Sea, 2001 \\
Heterocapsa triquetra (Dinophyceae) & SCCAP K-0481 & 1040 & SCCAP The Sound, Denmark, 1988 \\
Chrysochromulina ericina (Prymnesiophyceae) & CCMP 281 & 600 & CCMP \\
Heterosigma akashiwo (Raphidophyceae) & CCMP 2274 & 1900 & CCMP \\
\hline
\end{tabular}


per sample, except for the first few days when cell concentrations were below 200 cells ml $^{-1}$ and in the case of target species that were drastically reduced in abundance over the course of the experiment.

The exponential growth rate $\mu\left(\mathrm{d}^{-1}\right)$ was calculated separately for each replicate by linear regression of log (ln)-transformed cell number versus time for a time period indicated in Table 2. For replicate cultures, covariance analysis of regression lines using Statistica software (StatSoft) showed that exponential growth in replicate cultures did not differ significantly ( $p>0.1$ ); therefore, the exponential growth rate in the treatments was calculated using mean cell numbers of the 3 replicates, and treatments were compared using covariance analysis. The growth rate for 2 consecutive sampling dates was calculated as:

$$
\ln \left(\mathrm{N}_{t_{1}}\right)-\ln \left(\mathrm{N}_{t_{0}}\right) / t_{1}-t_{0}
$$

where $\mathrm{N}_{t_{1}}$ is the cell concentration at time $t_{1}$, and $\mathrm{N}_{t_{0}}$ is the initial cell number.

In this case, the growth rate was calculated for each replicate, and mono- and mixed cultures were compared using Student's $t$-tests.

Measurement of PSTs. After $25 \mathrm{~d}$ of growth at the early stationary phase, cells of the $2 A$. tamarense strains (Alex2 and Alex5) grown in monoculture were harvested for PST analysis. A $14 \mathrm{ml}$ sample of each monoculture was centrifuged $(3220 \times g, 10 \mathrm{~min}$ at $10^{\circ} \mathrm{C}$ ). Cell pellets were suspended in $1.0 \mathrm{ml}$ of $0.03 \mathrm{M}$ acetic acid and subsequently transferred into a FastPrep tube containing $0.9 \mathrm{~g}$ of lysing matrix $\mathrm{D}$. The samples were homogenized by reciprocal shaking at maximum speed $\left(6.5 \mathrm{~m} \mathrm{~s}^{-1}\right)$ for $45 \mathrm{~s}$ in a Bio101 FastPrep instrument (Thermo Savant). After homogenization, samples were centrifuged (Eppendorf $5415 \mathrm{R}$ ) at 16100 $\times g$ at $4^{\circ} \mathrm{C}$ for $15 \mathrm{~min}$. The supernatant $(400 \mu \mathrm{l})$ was transferred to a spin-filter (pore-size $0.45 \mu \mathrm{m}$, Millipore Ultrafree) and centrifuged for $30 \mathrm{~s}$ at $800 \times g$. The filtrate was transferred into an LC vial and analyzed by LC-FLD (liquid chromatography-fluorescence detection) with post-column derivatisation as described in Tillmann et al. (2009).

\section{RESULTS}

\section{Paralytic shellfish toxins in Alexandrium tamarense strains}

Both clonal strains of Alexandrium tamarense produced PSTs (Fig. 1). Cell quota of total PST were higher for Alex5 $\left(43 \mathrm{fmol} \mathrm{cell}^{-1}\right)$ than for Alex $2(27 \mathrm{fmol}$ cell $^{-1}$ ). PST profiles were quite similar for both strains, with saxitoxin (STX), neosaxitoxin (NEO) and Nsulphocarbamoyl $\mathrm{C}$ toxins being most prominent.

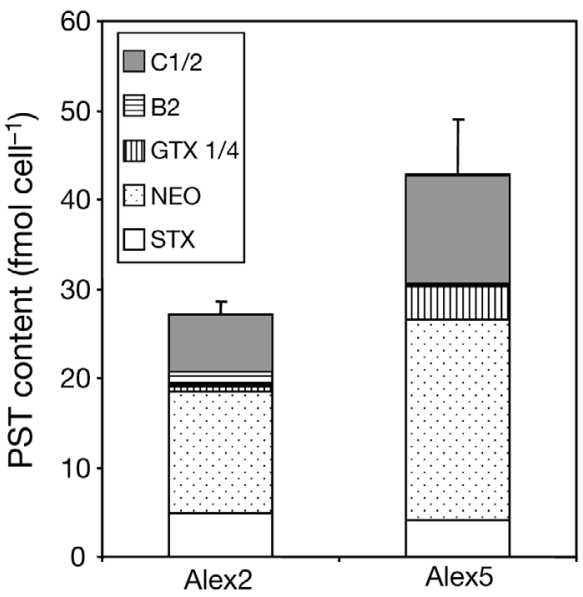

Fig. 1. Alexandrium tamarense. Paralytic shellfish toxin (PST) cell quota and composition of the 2 A. tamarense clones, Alex2 and Alex5. STX: saxitoxin; NEO: neosaxitoxin; GTX 1/4: gonyautoxin-1/4; B2: N-sulphocarbamoyl B2; C1/2: $\mathrm{N}$-sulphocarbamoyl $\mathrm{C} 1$ and $\mathrm{C} 2$. Minor compounds $\left(<0.05 \mathrm{fmol} \mathrm{cell}^{-1}\right)$ are not indicated in the key. Data are mean $(+\mathrm{SD})$ of $\mathrm{n}=3$ cultures

\section{Mixed growth experiments - growth of target species}

Growth curves of each target species in monoculture and in mixtures with Alexandrium tamarense strain Alex 2 or Alex5, as well as $\mathrm{pH}$ of the cultures, are summarised in Fig. 2. Growth curves of all target species were similar in monoculture and in mixed culture with Alex5. The exponential growth rate of the target species (Table 2) ranged from $0.36 \mathrm{~d}^{-1}$ (Prorocentrum minimum) to $1.48 \mathrm{~d}^{-1}$ (Skeletonema costatum). For all target species, exponential growth rates did not differ significantly between monocultures and mixed cultures with Alex5 (co-variance analysis, $\mathrm{p}>0.21$ ). In contrast, growth of the target species was drastically affected when cultured with Alex2. Dunaliella salina and Rhodomonas salina completely disappeared after $1 \mathrm{~d}$ of incubation. Cell counts of S. costatum and vegetative cells of Scrippsiella trochoidea immediately started to decline and became undetectable after 4 to $6 \mathrm{~d}$. Cell numbers of other target species initially increased but, after a few days, growth stopped, followed by a rapid population decline and complete die off after 10 to $15 \mathrm{~d}$. For unknown reasons, Ceratium lineatum (Fig. 2J) grew poorly both in monoculture and when mixed with Alex5. Nevertheless, when mixed with Alex2, cell numbers drastically declined and all cells disappeared after $6 \mathrm{~d}$.

In the case of Scrippsiella trochoidea (Fig. 2C), the number of vegetative cells sharply declined and temporary cysts appeared in cultures with Alex2. The number of cysts remained relatively stable at $52 \pm$ 14 cysts ml ${ }^{-1}$ (mean $\pm \mathrm{SD}$ ) over the course of the exper- 

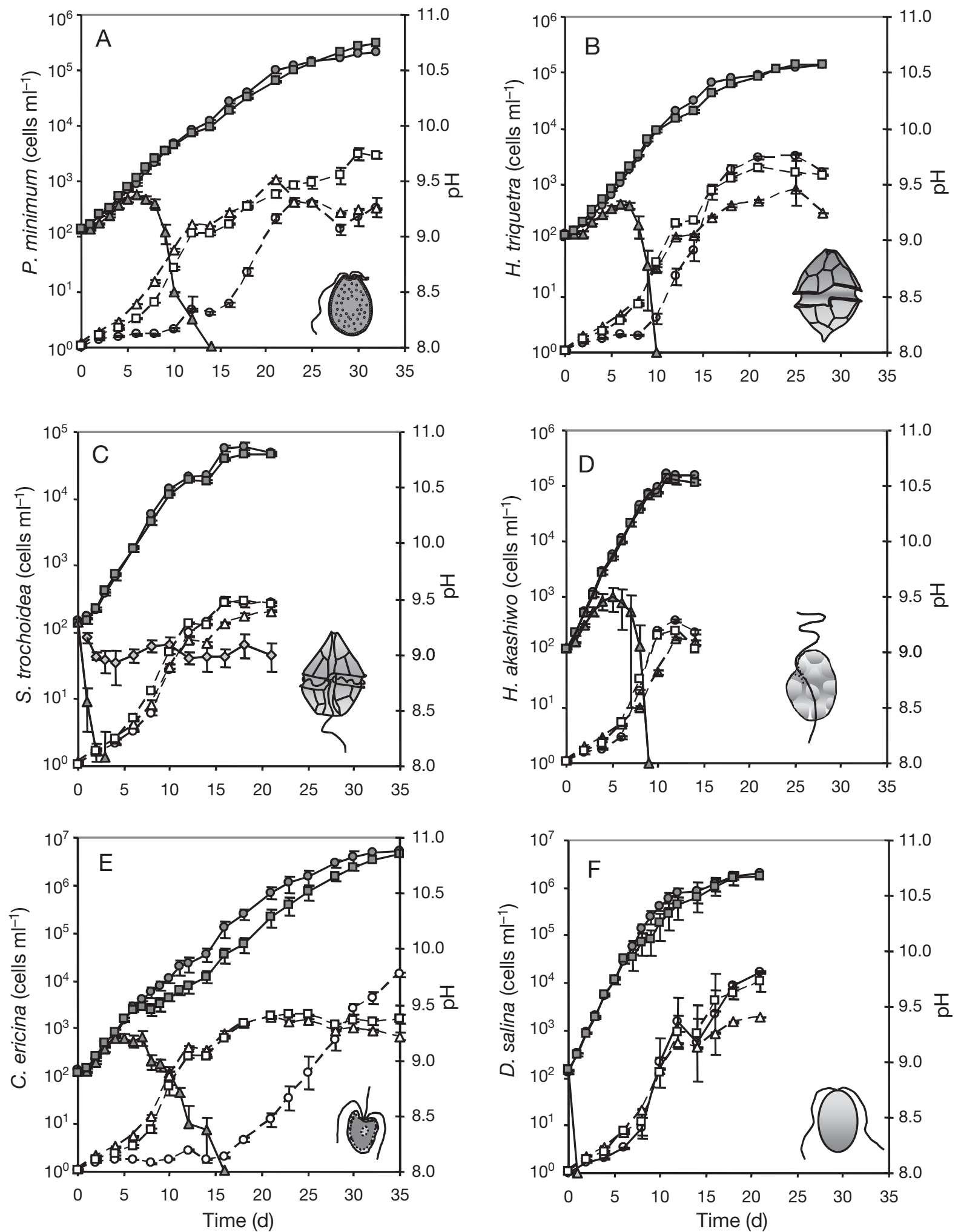

Fig. 2. (above and following page). Effect of Alexandrium tamarense on growth and survival of 10 different algal target species (see Table 1). (A-J) Average cell concentration (filled symbols) of individual algal species in monoculture (O), in mixed culture with Alex5 $(\square)$ and in mixed culture with Alex2 $(\Delta)$ as well as $\mathrm{pH}$ (open symbols) in monoculture (O), mixed culture with Alex5 $(\square)$ and mixed with Alex2 $(\Delta)$. Data are treatment means $( \pm 1 \mathrm{SD}), \mathrm{n}=3$. In Fig. $2 \mathrm{C}$ (Scrippsiella trochoidea), $(\Delta)$ refer to the abundance of vegetative cells and $(\diamond)$ refer to the abundance of temporary cysts 

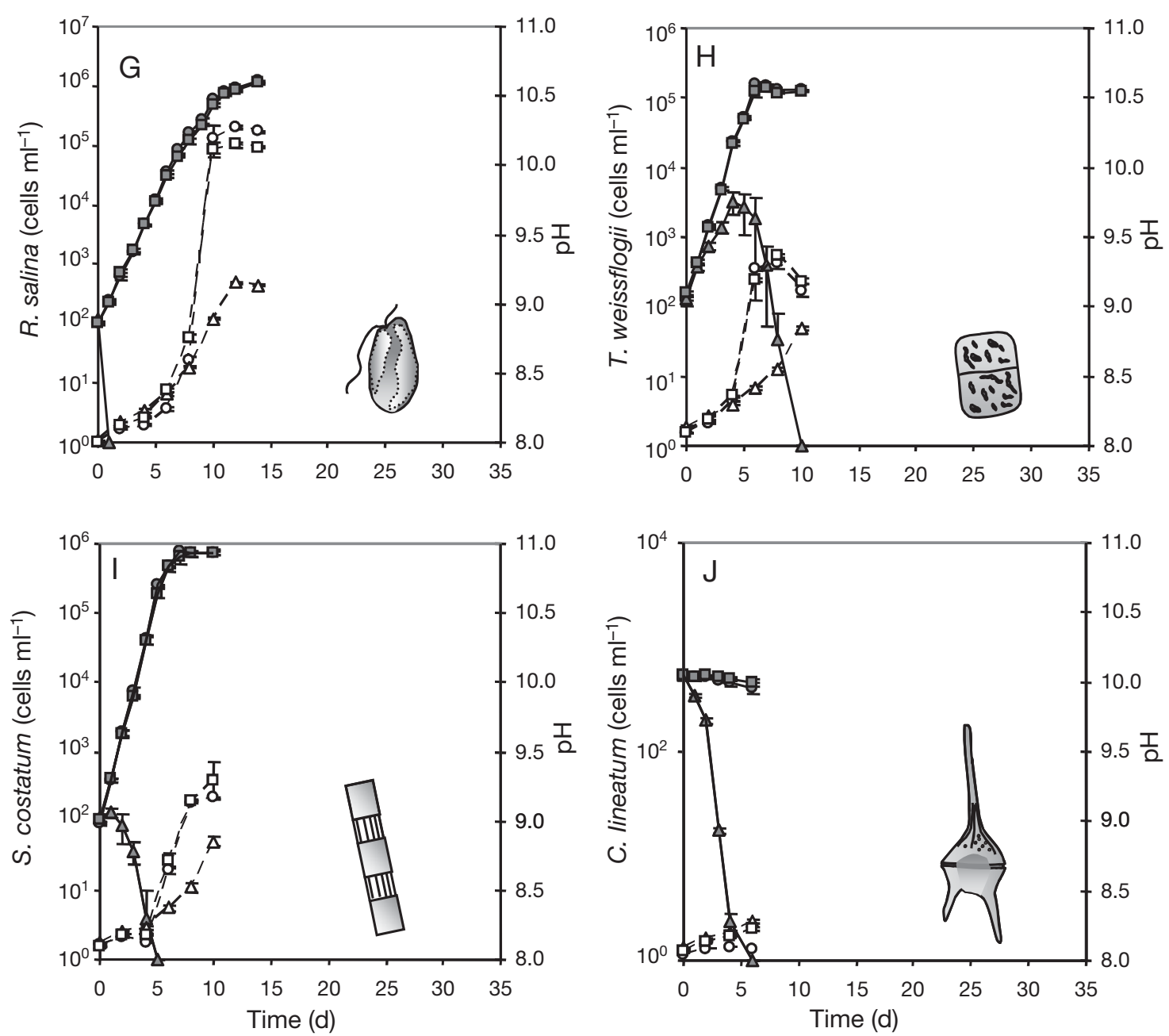

Fig. 2 (continued)

iment, indicating that roughly $1 / 3$ of the initial population successfully formed temporary cysts. In all cultures, $\mathrm{pH}$ increased with increasing cell densities from 8.0 to values well above 9 . It is important to note that a decline of target species in mixtures with Alex2 occurred at $\mathrm{pH}$ values well below that reached in the monocultures (>9).

Population dynamics of those target species that initially started to grow in mixed culture with Alex2 are shown in detail in Fig. 3. The exponential growth rate

Table 2. Growth rate $\mu\left(\mathrm{d}^{-1}\right)(95 \% \mathrm{CI})$ of target species in monoculture and with Alexandrium tamarense clones Alex5 and Alex2, calculated for the indicated time period

\begin{tabular}{|lcccc|}
\hline Species & Period $(\mathrm{d})$ & Monoculture & Alex5 & Alex2 \\
\hline Prorocentrum minimum & $1-8$ & $0.36(0.34-0.39)$ & $0.39(0.37-0.40)$ & $0.18(0.07-0.29)$ \\
Heterocapsa triquetra & $1-8$ & $0.44(0.40-0.48)$ & $0.46(0.44-0.47)$ & $0.13(-0.03-0.29)$ \\
Heterosigma akashiwo & $0-6$ & $0.79(0.75-0.83)$ & $0.76(0.72-0.80)$ & $0.38(0.22-0.53)$ \\
Chrysochromulina ericina & $1-6$ & $0.61(0.55-0.67)$ & $0.58(0.55-0.61)$ & $0.32(0.11-0.54)$ \\
Thalassiosira weissflogii & $0-6$ & $1.21(1.13-1.30)$ & $1.16(1.06-1.26)$ & $0.47(0.20-0.75)$ \\
Scrippsiella trochoidea & $1-6$ & $0.49(0.38-0.60)$ & $0.51(0.45-0.57)$ & $<<0$ \\
Skeletonema costatum & $0-6$ & $1.48(1.35-1.62)$ & $1.45(1.34-1.56)$ & $<<0$ \\
Dunaliella salina & $0-6$ & $0.90(0.87-0.93)$ & $0.91(0.85-0.96)$ & $<<0$ \\
Rhodomonas salina & $0-6$ & $0.98(0.95-1.01)$ & $0.95(0.92-0.98)$ & $<<0$ \\
Ceratium lineatum & $0-6$ & $-0.05[(-0.07)-(-0.03)]$ & $-0.03[(-0.02)-(-0.04)]$ & $<<0$ \\
\end{tabular}



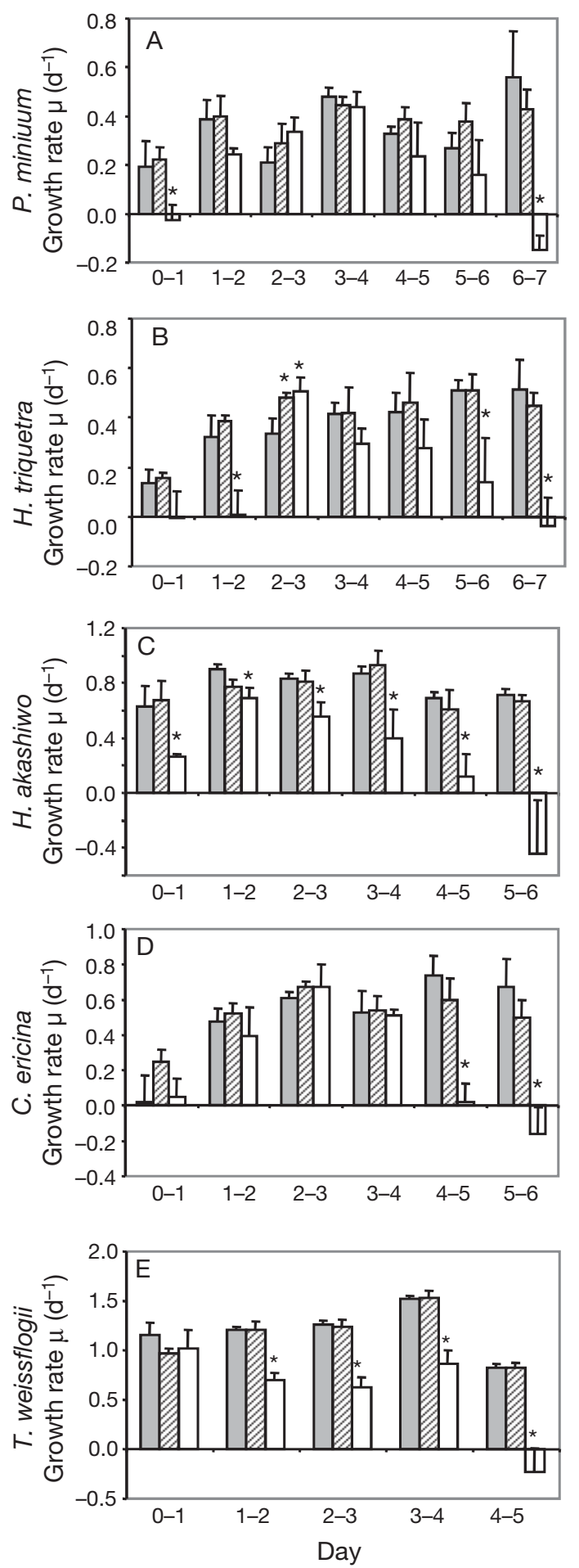

Fig. 3. Detailed initial dynamics of data shown in Fig. 2 for (A) Prorocentrum minium, (B) Heterocapsa triquetra, (C) Heterosigma akashiwo, (D) Chrysochromulina ericina; and (E) Thalassiosira weissflogii. Growth rate $\mu\left(\mathrm{d}^{-1}\right)$, calculated for each consecutive sampling day. Grey bars: monoculture; hatched bars: mixed culture with Alex5; open bars: mixed culture with Alex2. Data are treatment means $( \pm 1 \mathrm{SD}), \mathrm{n}=3$. *above bars indicate significant $(p<0.05)$ difference from monoculture of all species grown with Alex2 during the first 6 to $8 \mathrm{~d}$ was significantly $(p<0.05)$ reduced (Table 2$)$. However, calculating the growth rate for this time period is largely affected by the final decrease in cell number. Therefore, growth rate was calculated for each consecutive sampling day and here, species-specific differences became evident (Fig. 3).

Prorocentrum minimum, mixed with Alex2, showed a significant (compared to the monoculture) lag-phase of $1 \mathrm{~d}$. Thereafter, daily growth rates did not differ significantly from the control up to Day 6, when cell numbers started to decline. Likewise, Heterocapsa triquetra mixed with Alex2 showed a lag-phase of $2 \mathrm{~d}$, but resumed growth at a rate not significantly lower than in monocultures until Day 5. Following this, a positive but significantly reduced growth rate was observed for $1 \mathrm{~d}$ and, subsequently, cell numbers declined. Heterosigma akashiwo grown with Alex2 also showed a pronounced 1 d lag-phase, after which positive, but significantly reduced growth rates occurred until Day 5. In contrast, Chrysochromulina ericina and Thalassiosira weissflogii did not show a prolonged lag-phase compared to monocultures. C. ericina in mixture with Alex2 grew as fast as in monoculture until Day 4, when growth stopped and subsequently became negative. $T$. weissflogii grew with positive but significantly reduced rates until Day 4, after which the growth rate became negative.

Cell concentrations of Alex2 in mixed cultures at the time growth rates of the target species became negative are listed in Table 3. For Scrippsiella trochoidea, Dunaliella salina, Rhodomonas salina and Ceratium lineatum, mortality (decreasing cell numbers) had already occurred at the starting concentration of about 140 cells ml ${ }^{-1}$. After $1 \mathrm{~d}$, Skeletonema costatum started to decline at a concentration of 170 Alex $2 \mathrm{ml}^{-1}$. For all other targets, Alex2 concentrations causing population decline ranged from 700 to 1500 Alex2 ml-1.

Table 3. Concentration of Alexandrium tamarense clone Alex2 at which a population decline of the respective target species was observed. $<<140$ : population decline already occurred at the Alex2 start-concentration of 140 cells ml $^{-1}$

\begin{tabular}{|lcc|}
\hline Target species & $\begin{array}{c}\text { Day of } \\
\text { decline }\end{array}$ & $\begin{array}{c}\text { Alex2 concentration } \\
\text { (cells ml }^{-1} \text { ) }\end{array}$ \\
\hline Prorocentrum minimum & 6 & 1544 \\
Heterocapsa triquetra & 6 & 1221 \\
Heterosigma akashiwo & 5 & 967 \\
Chrysochromulina ericina & 4 & 737 \\
Thalassiosira weissflogii & 4 & 762 \\
Skeletonema costatum & 1 & 170 \\
Scrippsiella trochoidea & 0 & $<<140$ \\
Dunaliella salina & 0 & $<<140$ \\
Rhodomonas salina & 0 & $<<140$ \\
Ceratium lineatum & 0 & $<<140$ \\
\hline
\end{tabular}




\section{Mixed growth experiments - growth of Alexandrium tamarense}

In both mono- and mixed cultures, growth curves of Alex2 (Fig. 4A) and the corresponding $\mathrm{pH}$ dynamics (Fig 4B) were quite similar. The exponential growth rate of Alex2, calculated for the period Day 1 to 6, ranged from 0.43 to $0.48 \mathrm{~d}^{-1}$ (Table 4 ) and was not significantly different among treatments (co-variance analysis, $\mathrm{p}=0.14$ ).

Exponential growth rates for Alex5, again calculated for Day 1 to 6, was slightly lower compared to Alex2, ranging from 0.34 to $0.44 \mathrm{~d}^{-1}$ (Table 4). Despite this higher variabil-
Table 4. Alexandrium tamarense. Growth rate $\mu$ (95\% CI) of Alex2 and Alex 5 clones in mixed cultures for the period Day 1 to 6

\begin{tabular}{|c|c|c|}
\hline \multirow{2}{*}{ Cultured with } & \multicolumn{2}{|c|}{ Growth rate $\mu\left(\mathrm{d}^{-1}\right)$} \\
\hline & Alex2 & Alex5 \\
\hline Monoculture & $0.48(0.43-0.52)$ & $0.39(0.34-0.44)$ \\
\hline Prorocentrum minimum & $0.47(0.42-0.51)$ & $0.41(0.33-0.49)$ \\
\hline Heterocapsa triquetra & $0.43(0.37-0.48)$ & $0.41(0.37-0.46)$ \\
\hline Scrippsiella trochoidea & $0.49(0.46-0.52)$ & $0.44(0.39-0.50)$ \\
\hline Heterosigma akashiwo & $0.44(0.39-0.49)$ & $0.38(0.33-0.43)$ \\
\hline Chrysochromulina ericina & $0.47(0.42-0.52)$ & $0.38(0.32-0.44)$ \\
\hline Thalassiosira weissflogii & $0.48(0.46-0.50)$ & $0.34(0.30-0.38)$ \\
\hline Skeletonema costatum & $0.45(0.39-0.50)$ & $0.38(0.36-0.43)$ \\
\hline Dunaliella salina & $0.46(0.38-0.53)$ & $0.41(0.37-0.45)$ \\
\hline Rhodomonas salina & $0.45(0.42-0.47)$ & $0.40(0.34-0.47)$ \\
\hline Ceratium lineatum & $0.43(0.39-0.46)$ & $0.37(0.35-0.38)$ \\
\hline
\end{tabular}
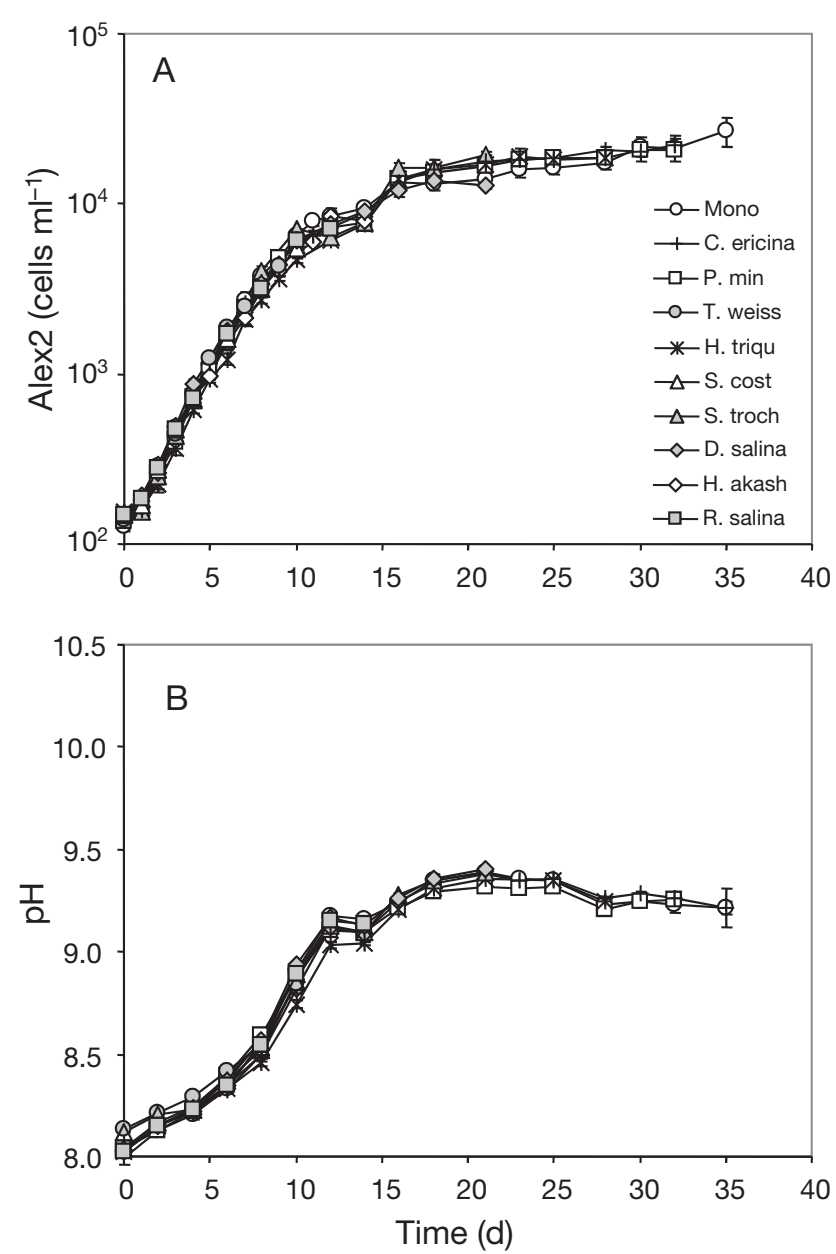

Fig. 4. (A) Growth of Alexandrium tamarense clone Alex2 and (B) $\mathrm{pH}$ in the monoculture (Mono) and in all mixed cultures. P. min: Prorocentrum minimum, H. triqu: Heterocapsa triquetra; S. troch: Scrippsiella trochoidea; H. akash: Heterosigma akashiwo; C. ericina: Chrysochromulina ericina; T. weiss: Thalassiosira weissflogii; S. cost: Skeletonema costatum; D. salina: Dunaliella salina; R. salina: Rhodomonas salina ity, co-variance analysis showed no significant differences among treatments $(p=0.078)$. Although the initial exponential growth rate of Alex 5 was similar for all treatments, full growth curves (Fig. 5A) as well as pH dynamics (Fig. 5B) differed substantially. In monoculture, fast exponential growth obviously ceased around Day 10 to 12 , when the $\mathrm{pH}$ reached values of $>9$. Nevertheless, cell numbers continuously increased up to $28 \times 10^{3} \mathrm{ml}^{-1}$ at the end of the experiment, together with a slow increase in $\mathrm{pH}$ up to 9.4. In contrast to the monoculture, rapid exponential growth of Alex5 in mixed cultures stopped earlier, and maximum cell numbers were lower for all treatments, except in mixed culture with Chrysochromulina ericina. Moreover, mortality of Alex5, indicated by declining cell numbers, was observed in several mixed cultures. A close inspection of $\mathrm{pH}$ dynamics indicate that (1) an increase in $\mathrm{pH}$ in the mixed cultures to values $>9$ coincides with the time when growth of Alex5 stopped, and (2) mortality of Alex5 occurred when $\mathrm{pH}$ in the mixed cultures reached values $>9.4$.

\section{DISCUSSION}

We studied the effect of Alexandrium tamarense on 10 other planktonic algal species in mixed growth experiments. To separate effects caused by allelochemicals from other effects like direct competition for nutrients or other interspecific interactions like mixotrophy or predation, our experiment was designed as a comparative approach using 2 different $A$. tamarense clonal strains that have been shown to differ in their potential to produce lytic extracellular compounds (Tillmann et al. 2009).

The 2 clones, Alex2 and Alex5, were deliberately selected out of 67 clonal strains originating from one 

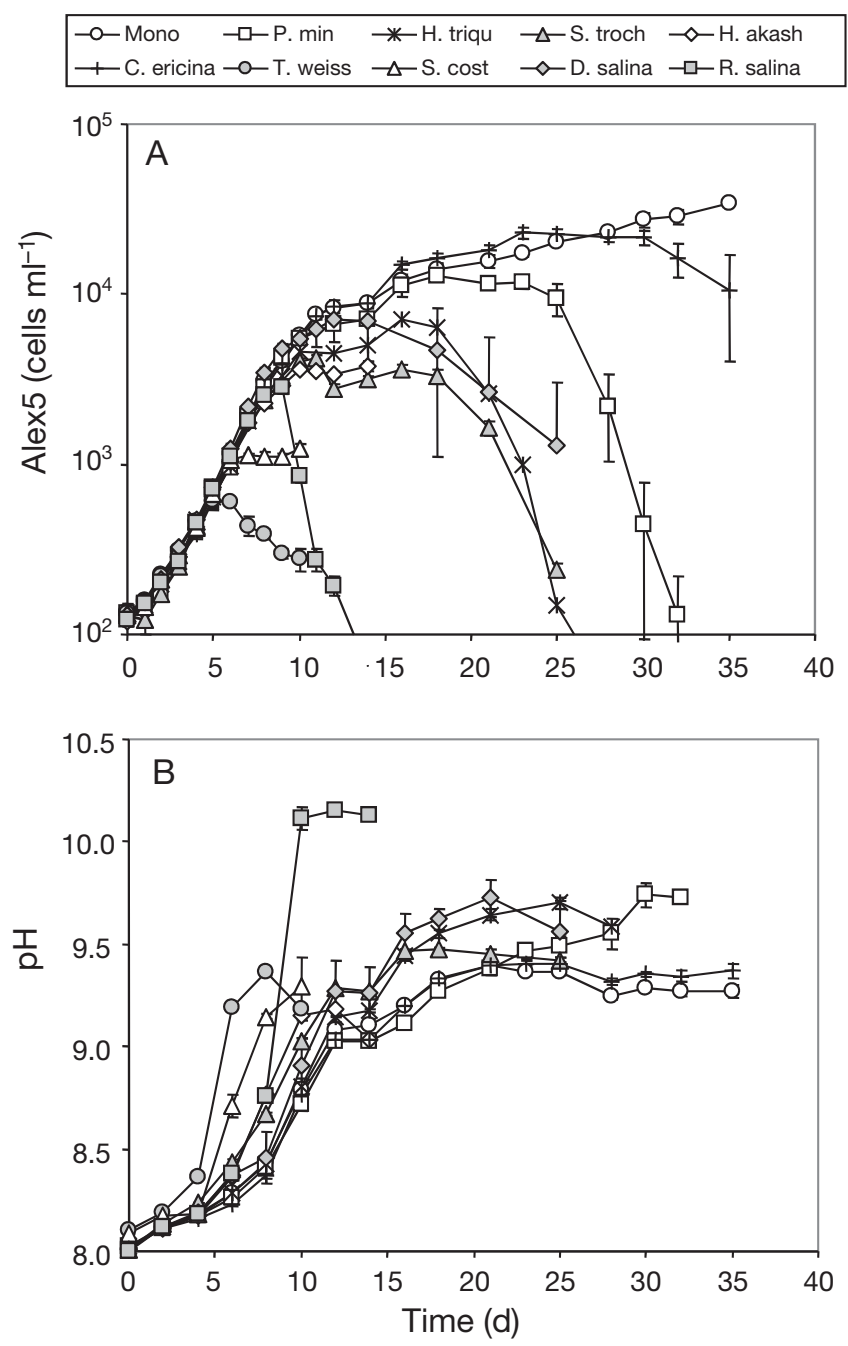

Fig. 5. Alexandrium tamarense. (A) Growth of Alex5 and (B) $\mathrm{pH}$ in monocultures (Mono) and in all mixture experiments. Species abbreviations as in Fig. 4

population, which were screened with respect to lytic potency by Alpermann et al. (Alpermann et al. in press). Among these 67 clones, only 2 isolates did not cause severe damage to Rhodomonas target cells, so the absence of measurable lytic activity in strains of Alexandrium tamarense seems to be a rare exception. The basic difference between Alex2 and Alex5 in allelochemical potency (Tillmann et al. 2009) is fully supported by the results from the present study: all target algae, which are common species in temperate waters and thus potentially co-occur and compete with A. tamarense in the North Sea, were clearly affected by the Alex2 strain. In contrast, the Alex5 strain had no negative effect on any of the target species during the study period, even though cell concentrations became very high $\left(2 \times 10^{4}\right.$ Alex $5 \mathrm{ml}^{-1}$ ). As both strains contain comparable amounts of PSTs, this also supports earlier reports suggesting that PSTs are not involved in the harmful effects of Alexandrium spp. on other algae (Tillmann \& John 2002, Fistarol et al. 2004b).

Based on the comparable growth rates of the 2 Alexandrium tamarense strains (Table 4), it can be assumed that they do not differ much with respect to their primary metabolism. Thus, their observed effects on target species in mixed culture can be attributed to allelochemical interactions caused by lytic secondary metabolites. pH can have a clear effect in mixed growth experiments and has to be taken into account in the interpretation of our results. This is because algae have different tolerances to high $\mathrm{pH}$ (Schmidt \& Hansen 2001, Hansen 2002), which evolves in non-aerated batch cultures like the ones used in the present study. However, in the experiments with Alex2, high $\mathrm{pH}$ could not explain the outcome. Here, the target algae were killed at a $\mathrm{pH}$ considerably lower than that which would affect their growth (Table 5). However, it is obvious that some of the target algae grew so dense and $\mathrm{pH}$ increased so much that it did kill the mixed cultures with Alex5 (Table 5, Fig. 5).

While all target species were obviously negatively affected by alleochemicals of strain Alex2, the growth of some species (Scrippsiella trochoidea, Dunaliella salina, Rhodomonas salina, Ceratium lineatum, Skeletonema costatum) was already affected at very low cell concentrations of Alex2. The influence of Alex2 on the growth of these species was detectable at the first sampling occasion (24 h) at an Alexandrium tamarense concentration of just above 100 Alex2 $\mathrm{ml}^{-1}$ (Fig.1). Mixed growth experiments with Alexandrium spp. and other

Table 5. Maximum $\mathrm{pH}$ in monocultures and $\mathrm{pH}$ in mixed cultures with Alex2 and Alex 5 at which growth of target species stopped. -: not measured

\begin{tabular}{|c|c|c|c|}
\hline Target species & $\begin{array}{l}\text { Mono- } \\
\text { cultures }\end{array}$ & $\begin{array}{c}\mathrm{pH} \\
\text { Mixed culture } \\
\text { (Alex2) }\end{array}$ & $\begin{array}{l}\text { Mixed culture } \\
\text { (Alex5) }\end{array}$ \\
\hline Ceratium lineatum & $8.7^{\mathrm{a}}$ & 8.2 & - \\
\hline Prorocentrum minimum & 9.75 & 8.4 & 9.75 \\
\hline Heterocapsa triquetra & 9.6 & 8.3 & 9.6 \\
\hline Scrippsiella trochoidea & 9.5 & 8.1 & 9.5 \\
\hline Heterosigma akashiwo & 9.3 & 8.3 & 9.3 \\
\hline Chrysochromulina ericina & 9.75 & 8.3 & 9.75 \\
\hline Thalassiosira weissflogii & 9.4 & 8.2 & 9.4 \\
\hline Skeletonema costatum & 9.4 & 8.1 & 9.4 \\
\hline Dunaliella salina & 9.75 & 8.1 & 9.75 \\
\hline Rhodomonas salina & 10.3 & 8.1 & 10.3 \\
\hline
\end{tabular}


species have not been carried out before, but acute lytic effects on other algae have been reported to occur within hours at this very low cell concentration. In short-term bioassays, the $\mathrm{EC}_{50}$ (Alexandrium spp. concentration causing lysis of $50 \%$ of the target population) of 10 clonal strains of $A$. tamarense for Rhodomonas as the target ranged from 80 to 640 cells $\mathrm{ml}^{-1}$ (Tillmann et al. 2009). For the same target, $\mathrm{EC}_{50}$ values of 230 to 520 cells ml $^{-1}$ were estimated for A. ostenfeldii, A. catenella and A. minutum (Tillmann et al. 2008a). Cell concentrations of only 20 to $170 \mathrm{cells} \mathrm{ml}^{-1}$ of these species also lysed $50 \%$ of a population of the chlorophyte $D$. salina within $24 \mathrm{~h}$ (Tillmann et al. 2008a), which is similar to our findings in the present study. Our results show that the growth of other species was not affected by Alex2 until the concentration reached ca. 600 Alex $\mathrm{ml}^{-1}$ (Heterocapsa triquetra, Prorocentrum minimum and Chrysochromulina ericina), and a decline in the cell concentration of these species was not achieved before Alex2 had reached a cell concentration of $\sim 700$ to 1500 Alex $2 \mathrm{ml}^{-1}$ (Table 3). Thus, it appears that some species are far more resistant to the allelochemicals produced by Alexandrium spp. than others. However, for a direct comparison of target sensitivity it has to be kept in mind that targets differ in various aspects probably relevant to lytic effects, like cell size or surface area (Tillmann et al. 2009). Nevertheless, structural properties probably also play an important role in susceptibility to extracellular allelochemicals, as the smallest target (C. ericina) was among the most resistant species and the largest target (C. lineatum) among the most susceptible ones (Fig. 2). Likewise, without any relationship to size, a few target species were found to be relatively refractory or even unaffected by extracellular compounds of $A$. ostenfeldii (Tillmann et al. 2007).

In the present study, complete die-off was the ultimate fate for most target species. The remarkable exception was Scrippsiella trochoidea: when mixed with Alex2, roughly $1 / 3$ of the initial population rapidly formed temporary cysts, the number of which remained constant during the course of the experiment. This observation is in agreement with a number of recent findings showing that temporary cyst formation may represent an inducible defence mechanism in response to deleterious chemical cues (Fistarol et al. 2004a, Toth et al. 2004, Tillmann et al. 2007). Temporary cysts of $S$. trochoidea are able to readily revert to a motile stage after a time-dependent degradation or inactivation of allelochemicals produced by Alexandrium ostenfeldii (Tillmann et al. 2007).

Thus, both quantitative (sensitivity) and qualitative (temporary cyst formation) responses to Alexandrium tamarense allelochemicals seem to be highly speciesspecific and, consequently, have the potential to cause temporal shifts in plankton community composition and succession (Fistarol et al. 2004b).

While a rapid population decrease of target species due to cell lysis seems to be the ultimate effect at sufficiently high Alexandrium tamarense concentrations, the data also show that, for some targets, a gradual decrease in growth rate of the target population can be observed at medium concentrations (Fig. 2). This may be either due to lysis of a certain percentage of the population while the rest is dividing at the same rate or because the compounds really slow down the growth rate of all individuals of the population. In any case, even a small reduction in the growth rate of competing species should benefit $A$. tamarense in gaining dominance in plankton communities.

The question remains as to whether our results can be generalised. In other words, will Alexandrium tamarense, by the production of allelochemicals, always win in competition with other algae? The answer to this question is clearly no. (1) A. tamarense clonal and strain differences in the amount of lytic compounds produced may be large (Alpermann et al. 2009). (2) There are species-specific differences in the sensitivity of the target species, and the question of potential strain variability in sensitivity of the target species has not yet been addressed experimentally. (3) Alexandrium spp. could be outcompeted by other, more $\mathrm{pH}$ tolerant species (see Hansen 2002) in eutrophic coastal waters, where $\mathrm{pH}$ values may, due to high primary production rates, increase to as much as 9.5 .

Lysis of target species is obviously dependent on the concentration of Alexandrium spp. cells. However, it also depends on the cell concentration of the targeted species (Tillmann 2003, Tillmann et al. 2007), which is probably due to compounds being removed by binding to the target membrane. This shows that the actual density of other protists (or, more generally, the density of all absorbing particles) may influence the effectiveness of extracellular allelochemicals. Abundance of the target and, more importantly, the abundance ratio of donor:target species are largely determined by the initial (as well as modified) growth rates of both target and donor species which, in turn, are a function of the given environmental growth conditions. Finally, there are probably additional and poorly known factors that determine the actual and effective concentration of extracellular allelochemicals. Physico-chemical degradation and adsorption of compounds, for example, is likely to be very important for the determination of whether and how compounds may accumulate during growth in batch culture. The interplay of factors and processes that finally decide whether Alexandrium will make it to a concentration representing a 'point of no return' for other species is very complex. 
Consequently, the outcome of these mixed growth experiments may be different for other clones/strains/ species, for different environmental conditions or even for other donor:target density ratios. Once cell density of a fast-growing target becomes high enough to either change the $\mathrm{pH}$ to unfavourably high values for Alexandrium spp. and/or to 'absorb' lytic compounds without acute cell lysis, this competitor might 'win' the mixed growth experiment in spite of its potential sensitivity to the allelochemicals produced by Alexandrium spp.

In any case, it is clear that lytic compounds have the potential to benefit Alexandrium tamarense by reducing competitor population growth. The potential relief of $A$. tamarense from competition for nutrients etc., together with the benefit of reducing grazing loss by protistan grazers (Hansen 1989, Tillmann \& John 2002, Fistarol et al. 2004b), is likely to be important for $A$. tamarense bloom development. Other advantages of lytic compounds are also conceivable: very recently, mixotrophy in A. tamarense has been described (Jeong et al. 2005). For a number of other mixotrophic harmful algal bloom (HAB) species, there is good evidence that toxic compounds are involved in prey immobilization and prey capture (Prymnesium: Skovgaard \& Hansen 2003, Tillmann 2003; Karlodinium: Adolf et al. 2007). However, in the present investigation, careful light microscopy inspection of many A. tamarense cells for the presence of food vacuoles yielded no indication of mixotrophy, and the growth rate of Alex2 in mixed cultures was not enhanced, either compared to the control or compared to the non-lytic strain Alex5. Experiments under limiting conditions (nutrient, light) monitoring the growth of $A$. tamarense in the presence of potential prey are needed to determine whether this species is capable of allelochemically enhanced mixotrophy.

Even though the chemical structure of the lytic compounds still remains to be determined, the ecological potency of these compounds, which may negatively affect both competitors and micrograzers, has been sufficiently demonstrated in laboratory experiments. Field studies on the ecological significance and importance of allelochemical interactions in natural populations, preferably at different stages of bloom formation of Alexandrium tamarense, now have to follow.

Acknowledgements. Thanks to B. Krock and A. Müller for PST analysis, to A. Tillmann for help with plankton counts, and to S. Pueppke for correcting the English.

\section{LITERATURE CITED}

Adolf J, Krupatkina D, Bachvaroff TR, Place AR (2007) Karlotoxin mediates grazing by Oxyrrhis marina on strains of Karlodinium veneficum. Harmful Algae 6:400-412

Alpermann T, Beszteri B, John U, Tillmann U, Cembella AD
(2009) Implications of life history transitions on the population genetic structure of the toxigenic marine dinoflagellate Alexandrium tamarense. Mol Ecol 18:2122-2133

Alpermann T, Tillmann U, Beszteri B, Cembella AD, John U (in press) Phaenotypic variation and genotypic diversity in a planktonic population of the toxigenic marine dinoflagellate Alexandrium tamarense. J Phycol

Cembella AD (2003) Chemical ecology of eukaryotic microalgae in marine ecosystems. Phycologia 42:420-447

Cembella AD, Quilliam MA, Lewis NI, Bauder AG and others (2002) The toxigenic marine dinoflagellate Alexandrium tamarense as the probable cause of mortality of caged salmon in Nova Scotia. Harmful Algae 1:313-325

Dahl E, Lindahl O, Paasche E, Throndsen J (1989) The Chrysochromulina polylepis bloom in Scandinavian waters during spring 1988. In: Cosper EM, Bricelj VM, Carpenter EJ (eds) Novel phytoplankton blooms: causes and impacts of recurrent brown tides and other unusual blooms. Springer Verlag, Berlin, p 383-405

Fistarol GO, Legrand C, Rengefors K, Granéli E (2004a) Temporary cysts formation in phytoplankton: a response to allelopathic competitors? Environ Microbiol 6:791-798

Fistarol GO, Legrand C, Selander E, Hummert C, Stolte W, Granéli E (2004b) Allelopathy in Alexandrium spp.: effect on natural plankton community and on algal monocultures. Aquat Microb Ecol 35:45-56

Fulco VK (2007) Harmful effects of the toxic dinoflagellate Alexandrium tamarense in the tintinnids Favella taraikaensis and Eutintinnus sp. J Mar Biol Assoc UK 87: 1085-1088

Granéli E, Hansen PJ (2006) Allelopathy in harmful algae: a mechanism to compete for resources? In: Granéli $\mathrm{E}$, Turner JT (eds) Ecology of harmful algae. Springer, Berlin, p 189-201

Hansen PJ (1989) The red tide dinoflagellate Alexandrium tamarense: effects on behaviour and growth of a tintinnid ciliate. Mar Ecol Prog Ser 53:105-116

> Hansen PJ (2002) Effect of high pH on the growth and survival of marine phytoplankton: implications for species succession. Aquat Microb Ecol 28:279-288

> Hansen PJ, Cembella AD, Moestrup Ø (1992) The marine dinoflagellate Alexandrium ostenfeldii: paralytic shellfish toxin concentration, composition, and toxicity to a tintinnid ciliate. J Phycol 28:597-603

Jeong HJ, Yoo YD, Park JY, Song JY and others (2005) Feeding by phototrophic red-tide dinoflagellates: 5 species newly revealed and 6 species previously known to be mixotrophic. Aquat Microb Ecol 40:133-150

Kamiyama T, Suzuki T (2006) Lack of accumulation of paralytic shellfish poisoning (PSP) toxins in the tintinnid ciliate Favella taraikaensis feeding on the toxic dinoflagellate Alexandrium tamarense. Mar Ecol Prog Ser 317:57-65

Keller MD, Selvin RC, Claus W, Guillard RRL (1987) Media for the culture of oceanic ultraphytoplankton. J Phycol 23: $633-638$

Legrand C, Rengefors K, Fistarol GO, Granéli E (2003) Allelopathy in phytoplankton-biochemical, ecological and evolutionary aspects. Phycologia 42:406-419

Mortensen AM (1985) Massive fish mortalities in the Faroe Islands caused by a Gonyaulax excavata red tide. In: Anderson DM, White AW, Baden DG (eds) Toxic dinoflagellates. Elsevier, Amsterdam, p 165-170

> Schmidt LE, Hansen PJ (2001) Allelopathy in the prymnesiophyte Chrysochromulina polylepis: effect of cell concentration, growth phase and $\mathrm{pH}$. Mar Ecol Prog Ser 216: $67-81$

Shimizu Y (1996) Microalgal metabolites: a new perspective. 
Annu Rev Microbiol 50:431-465

Skovgaard A, Hansen PJ (2003) Food uptake in the harmful alga Prymnesium parvum mediated by excreted toxins. Limnol Oceanogr 48:1161-1166

Sykes PF, Huntley ME (1987) Acute physiological reactions of Calanus pacificus to selected dinoflagellates: direct observations. Mar Biol 94:19-24

Tillmann U (2003) Kill and eat your predator: a winning strategy of the planktonic flagellate Prymnesium parvum. Aquat Microb Ecol 32:73-84

Tillmann U, John U (2002) Toxic effects of Alexandrium spp. on heterotrophic dinoflagellates: an allelochemical defence mechanism independent of PSP toxins. Mar Ecol Prog Ser 230:47-58

Tillmann U, John U, Cembella AD (2007) On the allelochemical potency of the marine dinoflagellate Alexandrium ostenfeldii against heterotrophic and autotrophic protists. J Plankton Res 29:527-543

Tillmann U, Alpermann T, John U, Cembella A (2008a) Allelochemical interactions and short-term effects of the dinoflagellate Alexandrium on selected photoautotrophic and heterotrophic protists. Harmful Algae 7:52-64

Editorial responsibility: Rutger de Wit, Montpellier, France
Tillmann U, John U, Krock B, Cembella A (2008b) Allelopathic effects of bioactive compounds produced by harmful algae. In: Moestrup O (ed) Proceedings of the 12th International Conference on Harmful Algae. International Society for the Study of Harmful Algae and Intergovernmental Oceanographic Commission of UNESCO, 2008, Kopenhagen, p 12-18

Tillmann U, Alpermann T, Purificacao R, Krock B, Cembella A (2009) Intra-population clonal variability in allelochemical potency of the toxigenic dinoflagellate Alexandrium tamarense. Harmful Algae 8:759-769

Toth GB, Norén F, Selander E, Pavia H (2004) Marine dinoflagellates show induced life-history shifts to escape parasite infection in response to water-borne signals. Proc R Soc Lond B 271:733-738

Turner JT, Tester PA, Hansen PJ (1998) Interactions between toxic marine phytoplankton and metazoan and protistan grazers. In: Anderson DA, Cembella AD, Hallegraeff GM (eds) Physiological ecology of harmful algal blooms. Springer, Berlin, p 453-474

Ulitzur S (1973) The amphiphatic nature of Prymnesium parvum hemolysin. Biochim Biophys Acta 298:673-679

Submitted: December 1, 2008; Accepted: May 19, 2009 Proofs received from author(s): September 2, 2009 